\title{
Left-wing authoritarianism is not a myth, but a worrisome reality. Evidence from 13 Eastern European countries ${ }^{\text {is }}$
}

\author{
Sabrina de Regt ${ }^{\mathrm{a}, *}$, Dimitri Mortelmans ${ }^{\mathrm{a}}$, Tim Smits ${ }^{\mathrm{b}}$ \\ ${ }^{a}$ University of Antwerp, Sint-Jacobsstraat 2, 2000 Antwerpen, Belgium \\ ${ }^{\mathrm{b}}$ Catholic University of Leuven, Leuven, Belgium
}

\section{Keywords:}

Left-wing authoritarianism

Support for democracy

Eastern Europe

European Values Study

\begin{abstract}
A B S T R A C T
A sometimes heated debate between authoritarianism researchers takes place on the issue of authoritarianism on the left. Some researchers argue that authoritarianism is typical for right-wing political orientation while other researchers assert that authoritarianism can also be found at the left side of the political spectrum. The aim of this paper is twofold. First, we aim to contribute to the ongoing discussion on left-wing authoritarianism. Using representative samples, the relationship between authoritarianism and political preferences is examined in 13 ex-communist Eastern European countries. Employing six different indicators of left-wing/communist political orientations make clear that, despite cross-national differences, left-wing authoritarianism is definitely not a myth in Eastern European countries. Second, it was aimed to survey whether authoritarian persons in Eastern European countries might be a possible threat for the transition to democracy. Based upon five items it was demonstrated that in general the Eastern European population seems to hold a positive opinion on democracy. However, it becomes also clear that authoritarian persons in the ex-communist countries are significantly less positive towards democracy.
\end{abstract}

(C) 2011 The Regents of the University of California. Published by Elsevier Ltd. All rights reserved.

\section{Introduction}

Is authoritarianism typical for ultra-right people like fascists, nationalists and racists? Or can individuals who advocate equality among people at the same time be authoritarian? This is a central discussion in authoritarianism research. Some researchers believe in psychological authoritarianism among leftists (Heaven and Connors, 1988; McClosky and Chong, 1985; Ray, 1983), while other authors consider that there is no supportive evidence for similarities in authoritarian personality between leftists and rightists (Brown, 1965; Tarr and Lorr, 1991). Many authors contributed to the discussion on the existence of left-wing authoritarianism trough reviewing the literature, giving theoretical reflections or by empirical examination (Funke, 1998; Kohn, 1972; Mullen et al., 2003; Ray, 1974; Taylor, 1960; Wilson et al., 1976). Conclusions regarding the existence of left-wing authoritarianism have been based mainly on investigations conducted in Western countries (Farnen, 1994). Even though several studies did examine the correlation between authoritarianism and political orientation in former communist countries, Eastern European countries are still underrepresented. In this paper we will analyze samples from 13 Eastern European countries. The aim of this paper is twofold. First, we will examine whether left-wing authoritarianism exists in those countries. Second, if authoritarianism seems to be positively correlated with left-wing/communist preferences an

\footnotetext{
An earlier version of this paper was presented at the 33rd Annual Scientific Meeting of the ISPP, San Francisco, CA USA, 7-10 July 2010.

* Corresponding author.
} 
important question is whether authoritarian individuals in Eastern Europe are a threat to the transition to a democratic political system.

We will use the European Values Study (EVS) to find an answer to our two research questions. This has several advantages. First, the same measures will be used across countries. Even though minimal differences in measurement bias might exist, using the same instrument across countries maximizes valid international comparisons. Second, the time span of our study is limited because we base our analysis on the third wave of the EVS. Therefore our results will be less biased because of possible country specific social developments that occur over time. Third, we will use representative samples and therefore the results might not only be limited to students as is often the case with authoritarianism research (Meloen, 1993). Last, we will examine these issues in a broad range of Eastern European countries. Until now some of those countries have not been studied yet.

\section{Classic studies on Authoritarianism and political orientation. Rigidity of the right}

In their search for an explanation for German Nazism Adorno et al. (1950) introduced the concept of The Authoritarian Personality. They assumed a linear association between conservative and fascistic ideas on the one hand and psychological irrationality on the other. As expected, their authoritarianism scale ( $F$ scale) correlated positively with ethnocentrism and political and economic conservatism (Adorno et al., 1950). Also in other studies it is shown that the $F$ scale correlates positively with political right-wing preferences and attitudes (Altemeyer, 1981; Farnen, 1994; Kirscht and Dillehay, 1967; Meloen, 1993).

Altemeyer (1981) reconceptualised authoritarianism to Right-Wing Authoritarianism (RWA) specified as the combination of three attitudinal clusters: (1) authoritarian submission - a high degree of submission to the authorities who perceived to be established and legitimate in the society where one lives (2) authoritarian aggression - a general aggressiveness, directed against various persons, which is perceived to be sanctioned by established authorities (3) conventionalism - a high degree of adherence to the social conventions that are perceived to be endorsed by society and its established authorities. Also RWA has proven to go hand in hand with preferences for right-wing political parties, general right-wing political orientation and specific right-wing beliefs and attitudes in different countries (Altemeyer, 1981; Crowson et al., 2005b; Duckitt, 1993; Feather, 1993; Liu et al., 2008; Van Hiel and Mervielde, 2002).

\section{Left-wing authoritarianism}

Shils (1954) was among the first to suggest the possibility of authoritarianism at the left pole of the political continuum. He noticed that fascism and Bolshevism had more in common than might be expected at first glance, for example, their common hostility towards civil liberties and political democracies, their common antipathy for parliamentary institutions, their conviction that all forms of power are in a hostile world concentrated in a few hands and their own aspirations for concentrated and total power (Shils, 1954). The fact that there exist authoritarian left-wing regimes does not imply however that authoritarian personality traits are as common among leftists as among rightists at the individual level. Or in other words, you have to be careful with shifting the level of analysis from a psychological level to a socio-political level (Stone and Smith, 1993).

Also Eysenck (1954) believed that authoritarianism could appear equally well on the left as on the right. He argued that all attitudes could be represented in terms of two axes: Radicalism vs. Conservatism and Tough-minded vs. Tender-minded. While fascists and communists differ in radicalism/conservatism they are expected to be the same in tough-mindedness (authoritarianism). Eysenck and Coulter (1972) concluded that communists and fascists were both more tough-minded compared to a control group. On the $F$ scale the fascists scored higher than the communists and the control group, but the communists scored higher than the control group. Eysenck's work has been severely critized, however, resulting in a fierce debate (Christie, 1956a, b; Eysenck, 1956a, b; Hanley and Rokeach, 1956; Rokeach and Hanley, 1956).

Another advocate of the movement away from the conceptualization and measurement of only rightist forms of authoritarianism is Rokeach $(1956,1960)$. He stated that a sharp distinction between the structure and the content of ideological systems is needed. In other words we should not focus upon what people think, but upon how they think. He developed the dogmatism scale to measure this general authoritarianism. He showed that communists have the lowest score on the $F$ scale while they score higher on dogmatism compared to other political groups. The differences on dogmatism between the communists and the other respondents were not significant however. Rokeach concluded that the dogmatism scale is relatively free of political content and because dogmatism is found with approximately equal frequency along all positions of the political spectrum the dogmatism scale is said to measure general authoritarianism (Rokeach, 1960). His thesis that dogmatism is unrelated to political ideology and therefore measures general authoritarianism is not supported in several studies (Barker, 1963; DiRenzo, 1967; Hanson, 1968, 1969, 1970; Knutson, 1974; Smithers and Lobley, 1978) reviewed by Stone (1980). Dogmatism scores were more associated with right-wing political ideologies. Based upon the reviewed studies, Stone (1980) concluded that left-wing authoritarianism is a myth because existing evidence suggests that authoritarianism is a personality and attitudinal syndrome characteristic of right-wingers alone. He stated that it seems a waste of time to continue to test a hypothesis with so little support as left-wing authoritarianism. Eysenck (1981) criticized Stones' review of the literature stating that 'it is not as factual or objective as it might be' and that 'a survey leaving out most of the evidence supporting the view the author is attacking can hardly be regarded as convincing scientifically'.

Altemeyer (1996) suggested that thus far researchers did not use the "the right stuff" conceptually and instrumentally and developed a new instrument to detect authoritarians living on the left bank of the political spectrum: the left-wing authoritarianism scale (LWA). He defined LWA as the covaration of the following three attitudinal clusters: (1) authoritarian 
submission - a high degree of submission to authorities who are dedicated to overthrowing the established authorities in one's society (2) authoritarian aggression - a general aggressiveness directed against the established authorities, or against persons who are perceived to support those authorities (3) conventionalism - a high degree of adherence to the norms of behaviour perceived to be endorsed by the revolutionary authorities. This scale contains the same attitudes as his RWA scale with the big difference that now submission to revolutionary authorities that want to overthrow the established authorities is used. Almost nobody scored above the neutral point of the LWA scale. Therefore Altemeyer concluded that he did not find 'a living, breathing, scientifically certifiable authoritarian on the left' calling them cynically Loch Ness Monsters.

With a newly developed LWA scale Van Hiel et al. (2006) found that in two samples of ordinary voters left-wing authoritarianism was almost absent. In a political activist sample left-wing authoritarianism was found among left-wing extremists however.

Looking for left-wing authoritarians in societies where the communist ideology has dominated for several decades has proven to be a fruitful approach. Multiple studies showed that in Hungary, Romania, Russia, Serbia and Yugoslavia authoritarianism correlates positively with support for: socialist ideology, socialist party preferences, positive feelings for communists, political left self-placement and communist principles (Enyedi and Todosijević, 2002; Krauss, 2002; McFarland et al., 1992, 1993, 1996; Pentony et al., 2000; Todosijević, 2005, 2006; Todosijević and Enyedi, 2008a, b).

\section{Hypotheses}

Conventionalism has always been considered to be a core aspect of authoritarianism. Adorno et al. (1950) stated that the conventionalists could in good conscience follow the dictates of the external agency wherever they might lead him and, moreover, he would be capable of totally exchanging one set of standards for another quite different one. Also Altemeyer (1981) included adherence to conventional norms as a core cluster of authoritarianism. He stated that authoritarians reject the idea that people should develop their own ideas of what is moral and immoral since these have already been determined by authorities. An authoritarian rejects the proposition that social customs are arbitrary, and one nation's customs can be seen as good as another's. Other ways of doing things are considered to be wrong (Altemeyer, 1981). After the Second World War Eastern Europe adopted communist modes of government until the fall of the Iron Curtain in 1989. Eastern European populations have been socialized into official communist ideology for four decades. Following the definition of authoritarianism, provided by Adorno et al. (1950), as well as Altemeyer (1981), we would expect authoritarian people in those countries to adhere to communist principles because right-wing political ideas have been largely absent for a quite long period.

Secondly, we will examine whether authoritarian people themselves in Eastern European countries can be a threat to the transition democracy. Altemeyer (1988) saw in authoritarian people a threat to freedom. The list of fearful consequences of authoritarianism is long. Among others, authoritarians are more likely to accept unfair and illegal abuses of power by government authorities; more likely to trust leaders who are untrustworthy; more likely to weaken constitutional guarantees of liberties; more likely to go easy on authorities who commit crimes and people who attack minorities; more likely to volunteer to help the government persecute almost everyone; and are more likely to seek dominance over others by being competitive and destructive in situations requiring cooperation (Altemeyer, 1996). Based on the above list of correlates of authoritarianism we expect Eastern European authoritarians to be a potential threat for the transition to a democratic political system. Some supportive evidence for this hypothesis is available from Eastern European countries. McFarland et al. (1993) find for example that both in North America and in the Soviet Union authoritarianism has been nondemocratic in the sense that authoritarian persons have been more prone to censure dissent and deny to out-groups full participation in the society. Also in another study in Russia it is shown that authoritarianism is negatively related to support of economic, political and intellectual freedoms and of democratic parties and organisations (McFarland et al., 1996). Krauss (2002) finds in Romania that correlations between authoritarianism and communism/anti-capitalism are high and positive; that authoritarianism was related to decreased support of forming alliances with the West and that authoritarianism was related to a decreased appreciation of the freedom that the revolution has brought with it. In this study we will examine the evaluation of democracy by authoritarians in 13 Eastern European countries by using the EVS which will be described below.

\section{Data and measurements}

\subsection{Data}

The European Values Study (EVS) is a large-scale, cross-national survey research program on basic human values. It provides insight into the ideas, beliefs, preferences, attitudes, values and opinions of citizens all over Europe. It is a unique research project on how Europeans think about life, family, work, religion, politics and society. For more information regarding translations of the questionnaire, sampling procedures, weighting and other important aspects of the EVS, see Inglehart et al. (2004) and www.europeanvaluesstudy.eu. In this article, we will use the third wave of the EVS. In 14 Eastern European countries face-to-face interviews were conducted with representative samples of adults aged 18 years and older. No upper age limit was imposed. Croatia had to be excluded from the analyses because of missing values on one of the authoritarianism items (whether obedience is an important quality that the children should learn at home). We used the Expectation-Maximization algorithm (Schafer, 1997) to impute missing values within a scale. In total, we analyze data from 15,524 persons. The specific sample sizes for the countries are displayed in Appendix A. 


\subsection{Measurements}

\subsubsection{Authoritarianism}

Altemeyer's Right-wing authoritarianism (RWA) scale is seen as the best current measure of the essence of what the authors of the authoritarian personality (TAP) were attempting to measure (Christie, 1991). Therefore we based our EVS authoritarianism scale on the three covariations of the RWA scale. Conventionalism is the first attitudinal cluster of the RWA scale. To measure this, we make use of items about whether respondents think that homosexuality, abortion, having casual sex, divorce and euthanasia are justified. The other aspects of authoritarianism are a high degree of submission to the established authorities and high levels of aggression in the name of these authorities. We use questions about unconditional love and respect for parents, need for having a strong leader who does not have to bother with parliament and elections, greater respect for authority in the future and whether obedience is an important quality children should learn at home to measure this component of authoritarianism. We did not use EVS items with special reference to religion to maximize the cross-national comparability. There exists a great variation between countries in number of persons who consider themselves religious (for example only 26 percent in Belarus, while more than 90 percent in Poland (own calculations EVS)). Also, only questions were used that were asked in (almost) all countries to maximize the inclusion of countries. Therefore, some interesting questions like 'would you be willing to fight for your country' and 'should books and films that attack religions be prohibited by law or should they be allowed' could not be included in this authoritarianism measurement.

The EVS authoritarianism scale has been validated elsewhere (de Regt et al., 2010). The EVS scale correlates substantially with the RWA (0.66) and the $F$ scale (0.50), has a higher internal consistency compared to the RWA and the $F$ scale and the predictive power of the EVS scale is comparable to that of the two other authoritarianism scales. Furthermore, the EVS authoritarianism scale is a measurement unit equivalent (Rock et al., 1978) indicating that we can meaningfully compare the effects of authoritarianism between countries. In Appendix A the country specific alpha's and some goodness of fit statistics of confirmatory factor analysis are displayed.

\subsubsection{Left-wing political preferences}

Six indicators are used to measure left-wing/communist political preferences. First, we examine political self-positioning "In political matters, people talk of "the left" and "the right." How would you place your views on this scale, generally speaking? $1=$ "Left' to $10=$ 'Righ". The second indicator of left-wing/communist political preferences is how people evaluate the political system as it was under communist regime 'People have different views about the system for governing this country. Here is a scale for rating how well things are going: 1 means very bad; 10 means very good. Where on this scale would you put the political system as it was under communist regime?'. Furthermore, four attitudinal questions were used to measure communist political preferences. Two concern the role of the state. One about individual responsibility vs. government responsibility 'People should take more responsibility to provide for themselves (1) vs. The government should take more responsibility to ensure that everyone is provided for (10)' and the other indicates whether people prefer free-market economy or a centralized economy 'The state should give more freedom to firms (1) vs. The state should control firms more effectively (10)'. The last two attitudes concern the communist principle of equality: the importance of eliminating big income inequalities 'In order to be considered “just", what a society should provide? Eliminating big inequalities in income between citizens ( 1 = 'Not at all important' to $5=$ 'Very important') and the importance of guaranteeing basic needs for all 'In order to be considered "just", what should a society provide? Guaranteeing that basic needs are met for all, in terms of food, housing, cloths, education, health ( 1 = 'Not at all important' to $5=$ 'Very important'). In Ukraine only four answer categories were provided for the two equality questions $(1=$ 'Not at all important' to $4=$ 'Very important').

\subsubsection{Evaluation of democracy}

In order to examine whether authoritarian people in Eastern Europe are a potential threat to the transition to a democracy five indicators were used concerning the evaluation of a democratic political system. First it is asked whether people think that a democratic political system in general is a good way of governing their country: 'I'm going to describe various types of political systems and ask you what you think about each as a way of governing this country. For each one, would you say it is very good (1), fairly good (2), fairly bad (3) or very bad way (4) of governing this country? - to have a democratic political system'. Furthermore, some more specific questions regarding the evaluation of a democratic system were used 'I'm going to read off some things that people sometimes say about a democratic political system. Could you please tell me if you agree strongly (1), agree (2), disagree (3) or disagree strongly (4)? (1) In democracy, the economic system runs badly; (2) Democracies are indecisive and have too much quibbling; (3) Democracies aren't good at maintaining order; and (4) Democracy may have problems but it's better than any other form of government. All variables are recoded so that a higher score indicates a negative evaluation of democracy.

\section{Results}

\subsection{Descriptive results}

In Table 1 we see that in all countries the average political self-positioning is around the mid-point of the scale with the exception of Russia. In Russia the population places itself on average more on the left compared to the population in other Eastern European countries. The average rating of the political system as it was under the communist regime is in all countries 
below the neutral scale point of 5.5, indicating that in general people hold negative views about the communist regime. Again the only exception is Russia. In Russia the average is slightly above the neutral point indicating a more positive view of the communist system of governing. Even though people in Eastern Europe seem not to be positive about the communist regime they do tend to agree with the communist principles. The overall average for the 13 Eastern European countries of all four attitudinal questions is above the neutral point (indicating a pro-communist attitude). There exists some cross-national variation however. Regarding the role of the state we can see in Table 1 that the average in some countries is below the neutral point. In some countries people think on average that individuals should take more responsibility to provide for themselves instead of the government (for example Lithuania) and that the state should give firms more freedom instead of controlling them effectively (for example Czech and Romania). Without exception, the mean of the equality indicators is above the neutral point in all Eastern European countries showing a strong adherence to the communist principles of equality in those countries.

In Table 2, the means of the democracy evaluation variables are displayed. On average the population of Eastern Europe thinks that having a democratic political system as a way of governing their country is 'very good' or 'fairly good'. Regarding the statement that in democracy the economic system runs badly, the Eastern European population on average holds more neutral views. The same seems to be true for the statements that democracies are indecisive and that democracies are not good at maintaining order. Also the last variable in Table 2 indicates that in general people in the ex-communist countries hold positive views regarding democracy. Again only in Russia people are on average somewhat less positive compared to the population of other Eastern European countries, but also in Russia the population holds on average a positive view of democracy as a form of government.

\subsection{Does left-wing authoritarianism exists?}

In Table 3 the results of the regression analyses of authoritarianism on left-wing/communist political orientation in 13 Central and Eastern European countries are displayed. Because we compare the effects across countries, unstandardized coefficients are reported instead of standardized regression coefficients (Tacq, 1997). If we examine the effect of authoritarianism on political self-positioning we see that there exists quite some variation in the Eastern European region. In some countries authoritarianism enhances political right self-positioning, for example, in Poland, Slovenia and Slovakia, while in other countries authoritarian individuals place themselves on the political left, like in Bulgaria, Belarus and Russia. In some countries the average effect of authoritarianism on political self-placement is found to be non-significant, for example, in the Baltic States. A quadratic effect was included in order to detect possible curvilinear relations. The quadratic effects of authoritarianism on political self-positioning were nevertheless small and non-significant and are therefore not displayed in the table.

If we look at the correlates of authoritarianism with the rating of the communist regime we see that in most countries authoritarianism enhances positive evaluations of the communist regime. Only in Hungary and Slovenia authoritarian people do not hold positive (or negative) views of the former communist regimes. Also in Lithuania, Latvia and Slovakia the effects are small and can be considered non-significant given the relatively large sample sizes.

If we consider the role of the state, we see (Table 3) that in almost all Central and Eastern European countries authoritarian people seem to want high levels of state control and intervention. Only in Latvia, Poland, Hungary and Lithuania the effect of authoritarianism on government responsibility (vs. individual responsibility) is weaker or non-significant. If we look at the relationship between authoritarianism and the communist principles of equality we see that in all countries authoritarian people think that it is important to eliminate big inequalities in income between citizens. The relationship between

Table 1

Means and standard deviations indicators left-wing/communist preferences. ${ }^{\text {a }}$

\begin{tabular}{|c|c|c|c|c|c|c|c|}
\hline & $n$ & $\begin{array}{l}\text { Political left } \\
\text { self-positioning } \\
(1-10)\end{array}$ & $\begin{array}{l}\text { Rate communist } \\
\text { political system } \\
(1-10)\end{array}$ & $\begin{array}{l}\text { Government } \\
\text { responsibility } \\
(1-10)\end{array}$ & $\begin{array}{l}\text { Firms and } \\
\text { freedom } \\
(1-10)\end{array}$ & $\begin{array}{l}\text { Importance eliminating } \\
\text { big income inequalities } \\
(1-5)\end{array}$ & $\begin{array}{l}\text { Importance } \\
\text { guaranteeing } \\
\text { basic needs for } \\
\text { all }(1-5)\end{array}$ \\
\hline Bulgaria & 973 & $5.66(2.12)$ & $4.75(2.84)$ & $5.46(3.09)$ & $5.27(2.84)$ & $3.92(1.22)$ & $4.58(0.77)$ \\
\hline Belarus & 960 & $5.46(1.54)$ & $5.26(2.48)$ & 4.97 (2.95) & $5.66(2.94)$ & $3.66(1.31)$ & $4.77(0.55)$ \\
\hline Czech & 1823 & $5.93(2.23)$ & $3.61(2.38)$ & $6.01(2.68)$ & $4.90(2.58)$ & $3.62(1.20)$ & $4.27(0.94)$ \\
\hline Estonia & 920 & $5.76(1.49)$ & $4.44(2.30)$ & $6.15(2.62)$ & $6.11(2.39)$ & $3.82(1.11)$ & $4.47(0.84)$ \\
\hline Hungary & 979 & $5.12(1.55)$ & $5.42(2.18)$ & $6.61(2.67)$ & $6.12(2.81)$ & $4.34(0.81)$ & $4.73(0.50)$ \\
\hline Latvia & 950 & $5.72(1.66)$ & $4.34(2.34)$ & $7.34(2.64)$ & $6.67(2.66)$ & 4.35 (0.97) & $4.76(0.62)$ \\
\hline Lithuania & 965 & $5.24(1.89)$ & $5.28(2.79)$ & $4.80(2.82)$ & $5.39(2.83)$ & 3.94 (1.19) & $4.70(0.63)$ \\
\hline Poland & 1063 & $5.32(2.07)$ & $4.46(2.56)$ & $6.60(2.97)$ & $5.78(2.59)$ & $4.18(1.01)$ & $4.67(0.74)$ \\
\hline Romania & 1109 & $5.57(1.81)$ & $4.57(2.96)$ & $6.20(3.33)$ & $4.87(3.18)$ & $4.18(0.91)$ & $4.57(0.61)$ \\
\hline Russia & 2423 & 4.85 (1.79) & $5.72(2.58)$ & $6.10(2.94)$ & $5.73(2.89)$ & $3.68(1.27)$ & $4.68(0.66)$ \\
\hline Slovakia & 1259 & $5.11(1.88)$ & $5.25(2.49)$ & $7.08(2.53)$ & $6.42(2.58)$ & $4.37(0.86)$ & $4.75(0.53)$ \\
\hline Slovenia & 955 & 5.09 (1.59) & $4.69(2.28)$ & $5.60(3.05)$ & $6.52(2.66)$ & $3.99(1.12)$ & $4.65(0.65)$ \\
\hline Ukraine & 1145 & $5.34(1.98)$ & $4.96(2.72)$ & $5.47(3.18)$ & 6.06 (2.99) & $3.08(1.00)$ & $3.84(0.45)$ \\
\hline Total & 15524 & 5.37 (1.89) & $4.85(2.62)$ & $6.05(2.97)$ & $5.75(2.83)$ & $3.96(1.10)^{\mathrm{b}}$ & $4.62(0.68)^{b}$ \\
\hline
\end{tabular}

a All country differences are significant F-test, $p<0.001$.

b Four instead of 5 answer categories. 
Table 2

Means and standard deviations democracy variables. ${ }^{\mathrm{a}, \mathrm{b}}$

\begin{tabular}{|c|c|c|c|c|c|}
\hline & $\begin{array}{l}\text { Having democratic } \\
\text { political system is bad }\end{array}$ & $\begin{array}{l}\text { In democracy the } \\
\text { economic system } \\
\text { runs badly }\end{array}$ & $\begin{array}{l}\text { Democracies are } \\
\text { indecisive and have } \\
\text { too much quibbling }\end{array}$ & $\begin{array}{l}\text { Democracies are } \\
\text { not good at } \\
\text { maintaining order }\end{array}$ & $\begin{array}{l}\text { Democracy worse } \\
\text { than any other form } \\
\text { of government }\end{array}$ \\
\hline Bulgaria & $1.80(0.73)$ & $2.39(0.75)$ & $2.48(0.76)$ & $2.34(0.77)$ & $1.83(0.75)$ \\
\hline Belarus & $1.82(0.63)$ & $2.29(0.66)$ & $2.44(0.72)$ & $2.40(0.76)$ & $1.85(0.63)$ \\
\hline Czech & $1.65(0.66)$ & $2.36(0.62)$ & $2.54(0.68)$ & $2.57(0.67)$ & $1.69(0.62)$ \\
\hline Estonia & $2.00(0.56)$ & $2.33(0.56)$ & $2.49(0.67)$ & $2.31(0.62)$ & $1.92(0.52)$ \\
\hline Hungary & $1.83(0.71)$ & $2.37(0.75)$ & $2.72(0.78)$ & $2.39(0.77)$ & $1.97(0.70)$ \\
\hline Latvia & $1.97(0.58)$ & $2.50(0.58)$ & $2.76(0.60)$ & $2.45(0.62)$ & $1.91(0.57)$ \\
\hline Lithuania & $1.97(0.63)$ & $2.48(0.62)$ & $2.74(0.67)$ & $2.59(0.63)$ & $1.99(0.60)$ \\
\hline Poland & $1.98(0.66)$ & $2.51(0.68)$ & $2.97(0.70)$ & $2.82(0.76)$ & $1.91(0.58)$ \\
\hline Romania & $1.82(0.73)$ & $2.60(0.86)$ & $2.91(0.83)$ & $2.51(0.90)$ & $1.96(0.82)$ \\
\hline Russia & $2.34(0.67)$ & $2.62(0.67)$ & $2.89(0.72)$ & $2.77(0.70)$ & $2.29(0.67)$ \\
\hline Slovakia & $1.91(0.76)$ & $2.50(0.79)$ & $2.63(0.80)$ & $2.40(0.87)$ & $1.89(0.72)$ \\
\hline Slovenia & $1.74(0.71)$ & $2.49(0.71)$ & $2.81(0.72)$ & $2.46(0.76)$ & $1.87(0.59)$ \\
\hline Ukraine & $2.01(0.64)$ & $2.40(0.62)$ & $2.62(0.70)$ & $2.53(0.67)$ & $1.99(0.62)$ \\
\hline Totaal & $1.94(0.70)$ & $2.46(0.69)$ & $2.71(0.74)$ & $2.53(0.75)$ & $1.95(0.68)$ \\
\hline
\end{tabular}

a All country differences are significant $F$-test, $p<0.001$.

b All variables have a 1-4 answer scale.

'Guaranteeing that basic needs are met for all, in terms of food, housing, cloths, education, health' and authoritarianism is less strong and non-significant in the Baltic States, Slovenia and Hungary. In the latter the effect is even positive, though not significantly, which might indicate a trend that authoritarian people in this country come to like instead of dislike inequality, more like we witness in Western European countries.

There are some small differences in the conclusion you might draw regarding left-wing authoritarianism in the individual countries depending on which variables you use. In Appendix B the countries are ranked for each of the six variables and a final country ranking is also displayed. It is shown that especially in Bulgaria, Belarus, Russia, Romania, and Ukraine authoritarianism is linked with left-wing/communist preferences. On the other hand this relation is less strong (and sometimes non-significant or even reversed) in countries like Hungary, Slovenia, Slovakia, Poland and the Baltic States.

\subsection{Are Eastern European authoritarians a possible threat to transition to democracy?}

If we look at the relationships between authoritarianism and the evaluation of the democratic political system in Table 4 we see that there is less variance between countries than we found earlier in the association between authoritarianism and left-wing/communist preferences. We see that in all countries authoritarianism is positively related to the democracy variables. This indicates that in all Central and Eastern European countries authoritarian people hold negative views about democracy. In all those ex-communist countries authoritarian oriented people believe that having a democratic political system is bad, that in democracy the economic system runs badly, that democracies are indecisive and have too much quibbling, that democracies are not good at maintaining order and that democracy is worse if compared to any other form of government. Especially in Romania this relation seems to be strong. Sometimes the association between authoritarianism and the evaluation of democracy is less strong in the Baltic States, Hungary and Ukraine, but in general it can be stated that authoritarian persons in the studied ex-communist countries hold negative views about the democratic political system.

Table 3

Unstandardized regression coefficients and (std. errors) of authoritarianism on left-wing/communist political orientation.

\begin{tabular}{|c|c|c|c|c|c|c|c|c|c|c|c|c|}
\hline \multirow[b]{2}{*}{ Bulgaria } & \multicolumn{2}{|c|}{$\begin{array}{l}\text { Political left } \\
\text { self-positioning }\end{array}$} & \multicolumn{2}{|c|}{$\begin{array}{l}\text { Rate communist } \\
\text { political system }\end{array}$} & \multicolumn{2}{|c|}{$\begin{array}{l}\text { Government } \\
\text { responsibility }\end{array}$} & \multicolumn{2}{|c|}{$\begin{array}{l}\text { State should } \\
\text { controle firms }\end{array}$} & \multicolumn{2}{|c|}{$\begin{array}{l}\text { Importance } \\
\text { eliminating big } \\
\text { income inequalities }\end{array}$} & \multicolumn{2}{|c|}{$\begin{array}{l}\text { Importance } \\
\text { guaranteeing } \\
\text { basic needs for all }\end{array}$} \\
\hline & $-0.032^{* * *}$ & $(0.005)$ & $0.028^{* * *}$ & $(0.007)$ & $0.040^{* * *}$ & $(0.007)$ & $0.029 * * *$ & $(0.008)$ & $0.023 * * *$ & $(0.003)$ & $0.009 * * *$ & $\overline{(0.002)}$ \\
\hline Belarus & $-0.019 * * *$ & $(0.004)$ & $0.029 * * *$ & $(0.006)$ & $0.032^{* * *}$ & $(0.007)$ & $0.060 * * *$ & $(0.007)$ & $0.031^{* * *}$ & $(0.003)$ & $0.003 *$ & $(0.001)$ \\
\hline Czech & $-0.016^{* * *}$ & $(0.004)$ & $0.032 * * *$ & $(0.004)$ & $0.022^{* * *}$ & $(0.004)$ & $0.021^{* * *}$ & $(0.004)$ & $0.022 * * *$ & $(0.002)$ & $0.007 * * *$ & $(0.002)$ \\
\hline Estonia & -0.005 & $(0.004)$ & $0.027 * * *$ & $(0.006)$ & $0.029 * * *$ & $(0.006)$ & $0.044^{* * *}$ & $(0.006)$ & $0.012 * * *$ & $(0.003)$ & $0.005^{*}$ & $(0.002)$ \\
\hline Hungary & $0.009 * *$ & $(0.004)$ & 0.006 & $(0.005)$ & $0.013^{*}$ & $(0.007)$ & 0.011 & $(0.006)$ & $0.008^{* * *}$ & $(0.002)$ & -0.001 & $(0.001)$ \\
\hline Latvia & 0.004 & $(0.004)$ & $0.013^{*}$ & $(0.006)$ & $0.021 * *$ & $(0.007)$ & $0.023 * *$ & $(0.007)$ & $0.013 * * *$ & $(0.003)$ & 0.003 & $(0.002)$ \\
\hline Lithuania & 0.009 & $(0.005)$ & $0.016^{*}$ & $(0.007)$ & 0.001 & $(0.007)$ & $0.023 * *$ & $(0.007)$ & $0.008^{* *}$ & $(0.003)$ & 0.001 & $(0.002)$ \\
\hline Poland & $0.018 * * *$ & $(0.004)$ & $0.032 * * *$ & $(0.005)$ & $0.017 * *$ & $(0.006)$ & $0.026 * * *$ & $(0.006)$ & $0.017 * * *$ & $(0.002)$ & $0.005^{* *}$ & $(0.002)$ \\
\hline Romania & $-0.015^{* * *}$ & $(0.004)$ & $0.078 * * *$ & $(0.007)$ & $0.031 * * *$ & $(0.007)$ & $0.073 * * *$ & $(0.008)$ & $0.011^{* * *}$ & $(0.002)$ & $0.004 * *$ & $(0.001)$ \\
\hline Russia & $-0.018^{* * *}$ & $(0.003)$ & $0.050^{* * *}$ & $(0.004)$ & $0.022^{* * *}$ & $(0.005)$ & $0.034^{* * *}$ & $(0.005)$ & $0.017^{* * *}$ & $(0.002)$ & $0.005^{* * *}$ & $(0.001)$ \\
\hline Slovakia & $0.009 * *$ & $(0.003)$ & $0.010^{*}$ & $(0.005)$ & $0.028^{* * *}$ & $(0.005)$ & $0.024^{* * *}$ & $(0.005)$ & $0.014^{* * *}$ & $(0.002)$ & $0.004^{* * *}$ & $(0.001)$ \\
\hline Slovenia & $0.019 * * *$ & $(0.003)$ & 0.004 & $(0.004)$ & $0.018^{* * *}$ & $(0.005)$ & $0.022 * * *$ & $(0.006)$ & $0.020 * * *$ & $(0.002)$ & 0.001 & $(0.001)$ \\
\hline Ukraine & -0.008 & $(0.005)$ & $0.030 * * *$ & $(0.006)$ & $0.032^{* * *}$ & $(0.007)$ & $0.051 * * *$ & $(0.007)$ & $0.020 * * *$ & $(0.002)$ & $0.003 * *$ & $(0.001)$ \\
\hline
\end{tabular}

${ }^{* * *} p<0.001 ;{ }^{* *} p<0.01 ;{ }^{*} p<0.05$. 
Table 4

Unstandardized regression coefficients and (std. errors) of authoritarianism on evaluation democracy.

\begin{tabular}{|c|c|c|c|c|c|c|c|c|c|c|}
\hline \multirow[b]{2}{*}{ Bulgaria } & \multicolumn{2}{|c|}{$\begin{array}{l}\text { Having a democratic } \\
\text { political system is bad }\end{array}$} & \multicolumn{2}{|c|}{$\begin{array}{l}\text { In democracy the } \\
\text { economic system } \\
\text { runs badly }\end{array}$} & \multicolumn{2}{|c|}{$\begin{array}{l}\text { Democracies are } \\
\text { indecisive and have } \\
\text { too much quibbling }\end{array}$} & \multicolumn{2}{|c|}{$\begin{array}{l}\text { Democracies aren't } \\
\text { good at maintaining } \\
\text { order }\end{array}$} & \multicolumn{2}{|c|}{$\begin{array}{l}\text { Democracy is worse } \\
\text { than any other form of } \\
\text { government }\end{array}$} \\
\hline & $0.007 * * *$ & $(0.002)$ & $0.010 * * *$ & $(0.002)$ & $0.009 * * *$ & $(0.002)$ & $0.012^{* * *}$ & $(0.002)$ & $0.006^{* * *}$ & $(0.002)$ \\
\hline Belarus & $0.009^{* * *}$ & $(0.001)$ & $0.012^{* * *}$ & $(0.002)$ & $0.011^{* * *}$ & $(0.002)$ & $0.012^{* * *}$ & $(0.002)$ & $0.009^{* * *}$ & $(0.001)$ \\
\hline Czech & $0.008 * * *$ & $(0.001)$ & $0.007 * * *$ & $(0.001)$ & $0.007^{* * *}$ & $(0.001)$ & $0.007^{* * *}$ & $(0.001)$ & $0.005^{* * *}$ & $(0.001)$ \\
\hline Estonia & $0.007 * * *$ & $(0.001)$ & $0.005^{* * *}$ & $(0.001)$ & $0.004^{*}$ & $(0.002)$ & $0.005^{* *}$ & $(0.002)$ & $0.004^{* *}$ & $(0.001)$ \\
\hline Hungary & $0.004^{* *}$ & $(0.002)$ & $0.013^{* * *}$ & $(0.002)$ & $0.005^{* *}$ & $(0.002)$ & $0.009 * * *$ & $(0.002)$ & $0.008^{* * *}$ & $(0.002)$ \\
\hline Latvia & $0.006 * * *$ & $(0.002)$ & $0.008 * * *$ & $(0.001)$ & $0.005^{* *}$ & $(0.002)$ & $0.007^{* * *}$ & $(0.002)$ & $0.004 * *$ & $(0.001)$ \\
\hline Lithuania & $0.005^{* *}$ & $(0.002)$ & $0.006 * * *$ & $(0.002)$ & $0.005^{* *}$ & $(0.002)$ & $0.005^{* *}$ & $(0.002)$ & $0.006^{* * *}$ & $(0.002)$ \\
\hline Poland & $0.006^{* * *}$ & $(0.001)$ & $0.009 * * *$ & $(0.001)$ & $0.006^{* * *}$ & $(0.002)$ & $0.007 * * *$ & $(0.002)$ & $0.007 * * *$ & $(0.001)$ \\
\hline Romania & $0.014^{* * *}$ & $(0.002)$ & $0.016^{* * *}$ & $(0.002)$ & $0.012^{* * *}$ & $(0.002)$ & $0.018^{* * *}$ & $(0.002)$ & $0.015^{* * *}$ & $(0.002)$ \\
\hline Russia & $0.009^{* * *}$ & $(0.001)$ & $0.011^{* * *}$ & $(0.001)$ & $0.011^{* * *}$ & $(0.001)$ & $0.009 * * *$ & $(0.001)$ & $0.009^{* * *}$ & $(0.001)$ \\
\hline Slovakia & $0.009 * * *$ & $(0.001)$ & $0.008 * * *$ & $(0.001)$ & $0.008 * * *$ & $(0.001)$ & $0.011^{* * *}$ & $(0.002)$ & $0.007 * * *$ & $(0.001)$ \\
\hline Slovenia & $0.009 * * *$ & $(0.001)$ & $0.012 * * *$ & $(0.001)$ & $0.011^{* * *}$ & $(0.001)$ & $0.010 * * *$ & $(0.002)$ & $0.007^{* * *}$ & $(0.001)$ \\
\hline Ukraine & $0.005^{* *}$ & $(0.001)$ & $0.009^{* * *}$ & $(0.001)$ & $0.005^{* * *}$ & $(0.002)$ & $0.004^{* *}$ & $(0.002)$ & $0.004^{*}$ & $(0.001)$ \\
\hline
\end{tabular}

${ }^{* * *} p<0.001,{ }^{* *} p<0.01,{ }^{*} p<0.05$.

\section{Discussion and conclusion}

The aim of this article was twofold. First we aimed to contribute to the ongoing discussion on left-wing authoritarianism. Using representative samples the relationship between authoritarianism and political preferences was examined in 13 excommunist Eastern European countries. Employing six different indicators of left-wing/communist political orientations made clear that, despite cross-national differences, left-wing authoritarianism is definitely not a myth in Eastern Europe. Secondly, it was aimed to survey whether authoritarian individuals in Eastern European countries might be a possible threat to transition to democratic political systems. It was demonstrated that in general the Eastern European population seems to hold a positive opinion on democracy. It becomes also clear however that the authoritarian persons in the ex-communist countries do not hold a positive perspective on the democratic political system.

Interesting is also the intra-regional variation regarding the relation between authoritarianism and political ideology. In Bulgaria and Russia, for example, authoritarianism is consequently linked with communist/political left-wing preferences regardless of which indicator is used; while in a country like Hungary almost no evidence was found for left-wing authoritarianism. This is in line with Todosijević and Enyedi's (2008a) conclusion that leftist authoritarians do exist in Hungary, but they are few and their presence is overshadowed by the authoritarianism of the anticommunist right. Also Enyedi et al. (1997) conclude that the phenomenon of left-wing authoritarianism, though present in Hungary, is less significant than its rightist counterpart. Schwartz and Bardi (1997) theorized that the level of communist penetration might explain those differences between countries within Eastern Europe. In Hungary, for example, until 1989 Soviet features characterized the political system, but in everyday life citizens were given considerable autonomy, and private moral was characterized by individualism and consumerism (Enyedi and Todosijević, 2002). Those findings make clear that we should not underestimate and ignore the intra-regional differences in Eastern Europe. It might be clear that findings from one Eastern Europe country should not be generalized too incautiously and applied to other Eastern European countries and that studying multiple countries might be essential to gain a deeper understanding of the correlates of authoritarianism is this region.

Public support is of course an essential ingredient for a successful transition to a capitalistic and democratic political system. In this article, it is shown that authoritarians in Central and Eastern European countries embrace communist principles and that they hold negative attitudes towards democracy. Therefore authoritarian persons in those countries might be a threat to transition to a democratic system. The Freedom House publishes annually an assessment of global political rights and civil liberties in the world. By the year when the EVS survey was held, the Freedom House rated 21 percent of the countries in Central and Eastern Europe as not free and 41 percent of the countries was rated as partly free (www.freedomhouse.org). This paper makes clear that authoritarianism should not be discarded as a factor that can endanger the transition to democracy. A deeper understanding of the antecedents and consequences of authoritarianism in the Central and Eastern European region seems therefore necessary.

All results presented in this paper are on the country level. This gives interesting information about general tendencies at the macro level and differences among the countries. It might also cover possible important differences at the individual level. There might be, for example, interesting age differences that are not exposed by the analyses at the country level. It can be expected that authoritarian persons in the generation that is socialized (mainly) after the fall of the Berlin Wall will not embrace communist principles while authoritarian persons that are socialized during communism do support those principles. Another example might be the difference between the 'winners' and the 'losers' of the transition. Research showed that the outcome of the transition process is not equally distributed among all socio-economic groups. The young, well-educated, high-wage earners and workers employed in private firms can be considered to be the winners of the transition process while the elderly, low-skilled and low-wage workers and the unemployed are the losers of this process (Doyle and Fidrmuc, 2003). In future studies age and socio-economic characteristics are, among others, interesting features at the individual level to examine who is authoritarian and left-wing in a left-wing authoritarian society. 
Given that conventionalism is seen as a central aspect of authoritarianism, it is a natural consequence that in excommunist countries' authoritarian persons support communist principles. This brings us back to the continuing debate how distinct authoritarianism is from conservatism. Some argue that the $F$ scale is indistinguishable from a measure of conservatism (Ray, 1973) and that Altemeyer's authoritarianism scale is also just another conservatism scale (Ray, 1985). Also Van Hiel et al. (2007) report serious problems of content overlap between, among others, the RWA scale and conservatism. Other authors argue that though authoritarianism and conservatism may be related, they are different constructs. While most authoritarian persons are conservative, this does not necessarily imply that most conservatives are authoritarian (Altemeyer, 1996). Also Stenner (2005) concluded that authoritarianism and political conservatism are distinct inclinations and results reported by Crowson et al. (2005a) indicate as well that conservatism is not synonymous with authoritarianism.

The existence of left-wing authoritarianism has been debated for about six decades. Many authors believed that authoritarianism is essentially a right-wing phenomenon. Most of the evidence comes from studies conducted in Western countries; while the members of the American Communist Part have always been treated as highly deviant (Krugman, 1952). Also Altemeyer (1981) described radical leftists in countries like Canada and the United States as not submissive to established authorities and not conventional. Therefore we believe that the fact that thus far not a lot of evidence is found for leftwing authoritarianism is not due to nonexistence of left-wing authoritarianism, but is due to the fact that we have not looked at the right places. This emphasizes again the importance of testing the generalisation of earlier research results and theoretical frameworks in a broad range of socio-political contexts. We believe this article showed that in Eastern Europe left-wing authoritarianism is not a myth, but a worrisome reality.

\section{Acknowledgement}

This study was funded by an interdisciplnary research grant (BOF) provided by the University of Antwerp. The sponsor had no role in design and conduct of the study

\section{Appendix A. Country specific samples sizes, authoritarianism alpha's and goodness of fit statistics confirmatory factor analysis. ${ }^{a}$}

\begin{tabular}{|c|c|c|c|c|c|c|}
\hline & $n$ & Alpha & df & $\chi^{2}$ & RMSEA & CFI \\
\hline Bulgaria & 973 & 0.73 & 27 & 89.34 & 0.049 & 0.96 \\
\hline Belarus & 960 & 0.69 & 27 & 117.60 & 0.059 & 0.92 \\
\hline Czech & 1823 & 0.70 & 27 & 146.18 & 0.049 & 0.96 \\
\hline Estonia & 920 & 0.73 & 27 & 81.58 & 0.047 & 0.97 \\
\hline Hungary & 979 & 0.70 & 27 & 69.61 & 0.040 & 0.97 \\
\hline Latvia & 950 & 0.65 & 27 & 37.62 & 0.020 & 0.99 \\
\hline Lithuania & 965 & 0.69 & 27 & 71.80 & 0.041 & 0.96 \\
\hline Poland & 1063 & 0.76 & 27 & 71.41 & 0.050 & 0.96 \\
\hline Romania & 1109 & 0.67 & 27 & 107.81 & 0.052 & 0.95 \\
\hline Russia & 2423 & 0.61 & 27 & 158.22 & 0.045 & 0.93 \\
\hline Slovakia & 1259 & 0.76 & 27 & 117.33 & 0.052 & 0.97 \\
\hline Slovenia & 955 & 0.73 & 27 & 104.75 & 0.055 & 0.96 \\
\hline Ukraine & 1145 & 0.70 & 27 & 99.22 & 0.048 & 0.96 \\
\hline
\end{tabular}

${ }^{a}$ Estimation method: WLS; RMSEA, Root Mean Square Error of Approximation (Steiger and Lind, 1980); RMSEA $<0.05$, good fit; $0.05<$ RMSEA $>0.08$, reasonable fit (Browne and Cudeck, 1993); CFI, Comparative Fit Index (Bentler, 1990); CFI > 0.90, good fit.

\section{Appendix B. Rank countries on left-wing authoritarianism.}

\begin{tabular}{|c|c|c|c|c|c|}
\hline \multicolumn{3}{|c|}{ Political left self-positioning } & \multicolumn{3}{|c|}{ Rate communist political system } \\
\hline Country & B & s.e & Country & B & s.e \\
\hline Bulgaria & $-0.032^{* * *}$ & $(0.005)$ & Romania & $0.078^{* * *}$ & $(0.007)$ \\
\hline Belarus & $-0.019^{* * *}$ & $(0.004)$ & Russia & $0.050^{* * *}$ & $(0.004)$ \\
\hline Russia & $-0.018^{* * *}$ & $(0.003)$ & Czech & $0.032^{* * *}$ & $(0.004)$ \\
\hline Czech & $-0.016^{* * *}$ & $(0.004)$ & Poland & $0.032^{* * *}$ & $(0.005)$ \\
\hline Romania & $-0.015^{* * *}$ & $(0.004)$ & Ukraine & $0.030^{* * *}$ & $(0.006)$ \\
\hline Ukraine & -0.008 & $(0.005)$ & Belarus & $0.029^{* * *}$ & $(0.006)$ \\
\hline Estonia & -0.005 & $(0.004)$ & Bulgaria & $0.028^{* * *}$ & $(0.007)$ \\
\hline Latvia & 0.004 & $(0.004)$ & Estonia & $0.027^{* * *}$ & $(0.006)$ \\
\hline Lithuania & 0.009 & $(0.005)$ & Lithuania & $0.016^{*}$ & $(0.007)$ \\
\hline Hungary & $0.009^{* *}$ & $(0.004)$ & Latvia & $0.013^{*}$ & $(0.006)$ \\
\hline Slovakia & $0.009^{* *}$ & $(0.003)$ & Slovakia & $0.010^{*}$ & $(0.005)$ \\
\hline Poland & $0.018^{* * *}$ & $(0.004)$ & Hungary & 0.006 & $(0.005)$ \\
\hline Slovenia & $0.019^{* * *}$ & $(0.003)$ & Slovenia & 0.004 & $(0.004)$ \\
\hline
\end{tabular}


Appendix B. (continued)

\begin{tabular}{|c|c|c|c|c|c|}
\hline \multicolumn{3}{|c|}{ Government responsibility } & \multicolumn{3}{|c|}{ State should control firms } \\
\hline Country & B & s.e & Country & B & s.e \\
\hline Bulgaria & $0.040^{* * *}$ & $(0.007)$ & Romania & $0.073^{* * *}$ & $(0.008)$ \\
\hline Belarus & $0.032^{* * *}$ & $(0.007)$ & Belarus & $0.060^{* * *}$ & $(0.007)$ \\
\hline Ukraine & $0.032^{* * *}$ & $(0.007)$ & Ukraine & $0.051^{* * *}$ & $(0.007)$ \\
\hline Romania & $0.031^{* * *}$ & $(0.007)$ & Estonia & $0.044^{* * *}$ & $(0.006)$ \\
\hline Estonia & $0.029^{* * *}$ & $(0.006)$ & Russia & $0.034^{* * *}$ & $(0.005)$ \\
\hline Slovakia & $0.028^{* * *}$ & $(0.005)$ & Bulgaria & $0.029^{* * *}$ & $(0.008)$ \\
\hline Russia & $0.022^{* * *}$ & $(0.005)$ & Poland & $0.026^{* * *}$ & $(0.006)$ \\
\hline Czech & $0.022^{* * *}$ & $(0.004)$ & Slovakia & $0.024^{* * *}$ & $(0.005)$ \\
\hline Latvia & $0.021^{* *}$ & $(0.007)$ & Lithuania & $0.023^{* * *}$ & $(0.007)$ \\
\hline Slovenia & $0.018^{* * *}$ & $(0.005)$ & Latvia & $0.023^{* * *}$ & $(0.007)$ \\
\hline Poland & $0.017^{* *}$ & $(0.006)$ & Slovenia & $0.022^{* * *}$ & $(0.006)$ \\
\hline Hungary & $0.013^{*}$ & $(0.007)$ & Czech & $0.021^{* * *}$ & $(0.004)$ \\
\hline Lithuania & 0.001 & $(0.007)$ & Hungary & $0.021^{* * *}$ & $(0.006)$ \\
\hline \multicolumn{3}{|c|}{ Importance eliminating big income inequalities } & \multicolumn{3}{|c|}{ Importance guaranteeing basic needs for all } \\
\hline Country & B & s.e & Country & B & s.e \\
\hline Belarus & $0.031^{* * *}$ & $(0.003)$ & Bulgaria & $0.009^{* * *}$ & $(0.002)$ \\
\hline Bulgaria & $0.023^{* * *}$ & $(0.003)$ & Czech & $0.007^{* * *}$ & $(0.002)$ \\
\hline Czech & $0.022^{* * *}$ & $(0.002)$ & Russia & $0.005^{* * *}$ & $(0.001)$ \\
\hline Slovenia & $0.020^{* * *}$ & $(0.002)$ & Poland & $0.005^{* *}$ & $(0.002)$ \\
\hline Ukraine & $0.020^{* * *}$ & $(0.002)$ & Estonia & $0.005^{*}$ & $(0.002)$ \\
\hline Russia & $0.017^{* * *}$ & $(0.002)$ & Slovakia & $0.004^{* * *}$ & $(0.001)$ \\
\hline Poland & $0.017^{* * *}$ & $(0.002)$ & Romania & $0.004^{* *}$ & $(0.001)$ \\
\hline Slovakia & $0.014^{* * *}$ & $(0.002)$ & Ukraine & $0.003^{* *}$ & $(0.001)$ \\
\hline Latvia & $0.013^{* * *}$ & $(0.003)$ & Belarus & $0.003^{*}$ & $(0.001)$ \\
\hline Estonia & $0.013^{* * *}$ & $(0.003)$ & Latvia & 0.003 & $(0.002)$ \\
\hline Romania & $0.011^{* * *}$ & $(0.002)$ & Lithuania & 0.001 & $(0.002)$ \\
\hline Hungary & $0.008^{* * *}$ & $(0.003)$ & Slovenia & 0.001 & $(0.001)$ \\
\hline Lithuania & $0.008^{* *}$ & $(0.003)$ & Hungary & -0.001 & $(0.001)$ \\
\hline Country & Rank & & & & \\
\hline Bulgaria & 1 & & & & \\
\hline Belarus & 2 & & & & \\
\hline Russia & 3 & & & & \\
\hline Romania & 4 & & & & \\
\hline Ukraine & 5 & & & & \\
\hline Czech & 6 & & & & \\
\hline Estonia & 7 & & & & \\
\hline Poland & 8 & & & & \\
\hline Slovakia & 9 & & & & \\
\hline Latvia & 10 & & & & \\
\hline Slovenia & 11 & & & & \\
\hline Lithuania & 12 & & & & \\
\hline Hungary & 13 & & & & \\
\hline
\end{tabular}

\section{References}

Adorno, T.W., Frenkel-Brunswik, E., Levinson, D.J., Sanford, R.N., 1950. The Authoritarian Personality. Harper, New York.

Altemeyer, B., 1981. Right-wing Authoritarianism. University of Manitoba Press, Winnipeg.

Altemeyer, B., 1988. Enemies of Freedom: Understanding Right-wing Authoritarianism. Jossey-Bass, San Francisco.

Altemeyer, B., 1996. The Authoritarian Spectre. Harvard University Press, Cambridge.

Barker, E.N., 1963. Authoritarianism of the political right, center, and left. Journal of Social Issues 19, 63-74.

Bentler, P.M., 1990. Comparative fit indexes in structural models. Psychological Bulletin 107, 238-246.

Brown, R., 1965. Social Psychology. Free Press, New York.

Browne, M.W., Cudeck, R., 1993. Alternative ways of assessing model fit. In: Bollen, K.A., Long, J.S. (Eds.), Testing Structural Equation Models. Sage, Newbury Park, pp. 445-455.

Christie, R., 1956a. Eysenck's treatment of the personality of communists. Psychological Bulletin 53, 411-430.

Christie, R., 1956b. Some abuses of psychology. Psychological Bulletin 53, 439-451.

Christie, R., 1991. Authoritarianism and related constructs. In: Robinson, J.P., Shaver, P.R., Wrightsman, L.S. (Eds.), Measures of Personality and Social Psychological Attitudes. Academic Press, San Diego.

Crowson, M., Thoma, S.J., Hestevold, N., 2005a. Is political conservatism synonymous with authoritarianism? The Journal of Social Psychology 145, 571-592. Crowson, M.H., DeBacker, T.K., Thoma, S.J., 2005b. Does authoritarianism predict post-9/11 attitudes? Personality and Individual Differences 39, $1273-1283$. DiRenzo, G.J., 1967. Professional politicians and personality structures. American Journal of Sociology 73, $217-225$.

Doyle, O., Fidrmuc, J., 2003. Anatomy of voting behaviour and attitudes during post-communist transition: Czech Republic 1990-1998. In: Campos, M., Fidrmuc, J. (Eds.), Political Economy of Transition and Development: Institutions, Politics and Policies. ZEI Studies in European Economics and Law. Kluwer Academic Publishers, Boston, pp. 139-163. 
Duckitt, J., 1993. Right-wing authoritarianism among white South African students: its measurement and correlates. The Journal of Social Psychology 133, 553-563.

Enyedi, Z., Todosijević, B., 2002. Authoritarianism and political orientations in Hungary.

Enyedi, Z., Eros, F., Fábián, Z., 1997. Authoritarianism and the ideological spectrum in Hungary.

Eysenck, H.J., 1954. Psychology of Politics. Routledge \& Kegan Paul, London.

Eysenck, H.J., 1956a. The psychology of politics and the personality similarities between fascists and communists. Psychological Bulletin 53, 431-438.

Eysenck, H.J., 1956b. The psychology of politics: a reply. Psychological Bulletin 53, 177-182.

Eysenck, H.J., 1981. Left-wing authoritarianism: myth or reality? Political Psychology 3, 234-239.

Eysenck, H.J., Coulter, T.T., 1972. The personality and attitudes of working class British communist and fascists. Journal of Social Psychology 87, 59-73.

Farnen, R., 1994. Nationalism, Ethnicity, and Identity: Cross-national and Comparative Perspectives. Transaction Publishers, New Brunswick.

Feather, N.T., 1993. Authoritarianism and attitudes toward high achievers. Journal of Personality and Social Psychology $1993,1$.

Funke, F., 1998. What is "left" from left authoritarianism?

Hanley, C., Rokeach, M., 1956. Care and Carelessness in psychology. Psychological Bulletin 53, 183-186.

Hanson, D.J., 1968. Dogmatism and authoritarianism. Journal of Social Psychology 76, 89-95.

Hanson, D.J., 1969. Dogmatism among authoritarians of the right and the left. Psychological Studies 14, 12-21.

Hanson, D.J., 1970. Validity test of the dogmatism scale. Psychological Reports 26, 585-586.

Heaven, P.C.L., Connors, J., 1988. Politics and toughmindedness. The Journal of Social Psychology 128, 217-222.

Inglehart, R., Basáňez, M., Díez-Medrano, J., Halman, L., Luijkx, R., 2004. Human Beliefs and Values: A Cross-cultural Sourcebook Based on The 1999-2002

Values Surveys. Siglo XXI, Mexico City.

Kirscht, J.P., Dillehay, R.C., 1967. Dimensions of Authoritarianism: A Review of Research and Theory. University of Kentucky Press, Lexington.

Knutson, J.N., 1974. Psychological Variables in Political Recruitment. The Wright Institute, Mimeo, Berkeley.

Kohn, P.M., 1972. The authoritarian-rebellion scale: a balanced F-scale with left-wing reversals. Sociometry 35, 176-189.

Krauss, W., 2002. Romanian authoritarianism 10 years after communism. Personality and Social Psychology Bulletin 28, 1255-1264.

Krugman, H., 1952. The appeal of communism to American middle class intellectuals and trade unionists. Public Opinion Quarterly 16, 331-335.

Liu, J.H., Huang, L.-L., McFedries, C., 2008. Cross-sectional and longitudinal differences in social dominance orientation and right wing authoritarianism as a function of political power and societal change. Asian Journal of Social Psychology 11, 116-126.

McClosky, H., Chong, D., 1985. Similarities and differences between left-wing and right-wing radicals. British Journal of Political Science 15, $329-363$.

McFarland, S.G., Ageyev, V.S., Abalakina-Paap, M.A., 1992. Authoritarianism in the former Soviet Union. Journal of Personality and Social Psychology 63, 1004-1010.

McFarland, S.G., Ageyev, V.S., Abalakina-Paap, M.A., 1993. The authoritarian personality in the United States and the former Soviet Union: comparative studies. In: Stone, W.F., Lederer, G., Christie, R. (Eds.), Strength and Weakness. The Authoritarian Personality Today. Springler Verlag, New York.

McFarland, S.G., Ageyev, V.S., Djintcharadze, N., 1996. Russian authoritarianism two years after communism. Personality and Social Psychology Bulletin 22, 210-217.

Meloen, J., 1993. The $F$ scale as predictor of fascism: an overview of 40 years of authoritarianism research. In: Stone, W.F., Lederer, G., Christie, R. (Eds.), Strength and Weakness. The Authoritarian Personality Today. Springer Verlag, New York, pp. 47-69.

Mullen, E., Bauman, C., Skitka, L.J., 2003. Avoiding the pitfalls of politicized psychology. Analyses of Social Issues and Public Policy 3, $171-176$.

Pentony, J.F., Peterson, K.S.E., Philips, O., Leong, C., Harper, P., Bakowski, A., Steward, S., Gonzales, R., 2000. A comparison of authoritarianism in the United States, England, and Hungary with selected nonrandom samples. European Psychologist 5, 259-268.

Ray, J.J., 1973. Conservatism, authoritarianism, and related variables: a review and empiricalstudy. In: Wilson, G. (Ed.), The Psychology of Conservatism. Academic Press, London.

Ray, J.J., 1974. Authoritarian humanism. In: Ray, J.J. (Ed.), Conservatism as Heresy. A.N.Z. Book Co., Sydney.

Ray, J.J., 1983. Half of all authoritarians are left-wing: a reply to Eysenck and Stone. Political Psychology 4, 139-143.

Ray, J.J., 1985. Defective validity in the Altemeyer authoritarianism scale. The Journal of Social Psychology 125, 271-272.

de Regt, S., Smits, T., Mortelmans, D., 2010. On cross-national variation in the correlation between authoritarianism and social dominance orientation. Politics, Culture and Socialization 1 (4), 311-322.

Rock, D.A., Werts, C.E., Flaugher, R.L., 1978. The use of analysis of covariance structures for comparing the psychometric properties of multiple variables across populations. Multivariate Behavioral Research 13, 403-418.

Rokeach, M., 1956. Political and religious dogmatism: an alternative to the authoritarian personality. Psychological Monographs 70, 1-43.

Rokeach, M., 1960. The Open and Closed Mind: Investigations into the Source of Beliefs Systems and Personality Systems. Basic Books, New York.

Rokeach, M., Hanley, C., 1956. Eysenck's tender-mindedness dimension: a critique. Psychological Bulletin 53, $169-176$.

Schafer, J.L., 1997. Analysis of Incomplete Multivariate Data. Chapman \& Hall, London.

Schwartz, S.H., Bardi, A., 1997. Influences of adaption to communist rule on value priorities in Eastern Europe. Political Psychology 18 , 385-410.

Shils, E.A., 1954. Authoritarianism: right and left. In: Christie, R., Jahoda, M. (Eds.), Studies in the Scope and the Method of the Authoritarian Personality. Free Press, New York.

Smithers, A.G., Lobley, D.M., 1978. The relationship between dogmatism and radicalism/conservatism. In: Eysenck, H.J., Wilson, G. (Eds.), The Psychological Basis of Ideology. MTP Press Limited, Lancaster.

Steiger, J.H., Lind, J.C., 1980. Statistically based tests for the number of common factors. Annual Meeting of The Psychometric Society, Iowa City, IA.

Stenner, K., 2005. The Authoritarian Dynamic. Cambridge University Press, Cambridge.

Stone, W.F., 1980. The myth of left wing authoritarianism. Political Psychology 2, 3-19.

Stone, W.F., Smith, L.D., 1993. Authoritarianism: left and right. In: Stone, W.F., Lederer, G., Christie, R. (Eds.), Strength and Weakness: The Authoritarian Personality Today. Springer Verlag, New York, pp. 144-156.

Tacq, J., 1997. Multivariate Analysis Techniques in Social Science Research. From Problem to Analysis. Sage, London.

Tarr, H., Lorr, M., 1991. A comparison of right-wing authoritarianism conformity and conservatism. Personality and Individual Differences 12, 307-311.

Taylor, I.A., 1960. Similarities in the structure of extreme social attitudes. Psychological Monographs 74, 1-32.

Todosijević, B., 2005. Authoritarianism and socialist ideology: the case of Yugoslavia, 1995. In: Farnen, R.F., Dekker, H., De Landtsheer, C., Sünker, H., German, D.B. (Eds.), Democratization, Europeanization, and Globalization Trends: Cross-national Analysis of Authoritarianism, Socialization, Communications, Youth, and Social Policy. Peter Lang, Frankfurt.

Todosijević, B., 2006. Politics in Serbia 1990-2002: a cleavage of world views. Psihologija 39, 121-146.

Todosijević, B., Enyedi, Z., 2008a. Authoritarianism without dominant ideology: political manifestations of authoritarian attitudes in Hungary. Political Psychology 29, 767-787.

Todosijević, B., Enyedi, Z., 2008b. Post-materialism and authoritarianism in Hungary: evidence from a two-generations study. In: Farnen, R., German, D., Dekker, H., De Landtsheer, C., Sünker, H. (Eds.), Political Culture, Socialization, Democracy, and Education: Interdisciplinary and Cross-National Perspectives for a New Century. Peter Lang, Frankfurt am Main, pp. 77-97.

Van Hiel, A., Mervielde, I., 2002. Explaining conservative beliefs and political preferences: a comparison of social dominance orientation and authoritarianism. Journal of Applied Social Psychology 32, 965-976.

Van Hiel, A., Duriez, B., Kossowska, M., 2006. The presence of left-wing authoritarianism in Western-Europe and its relationship with conservative ideology Political Psychology 27, 769-793.

Van Hiel, A., Cornelis, I., Roets, A., De Clercq, B., 2007. A comparison of various authoritarianism scales in Belgian Flanders. European Journal of Personality 21, 149-168.

Wilson, W., Dennis, L., Wadsworth jr, A.P., 1976. “Authoritarianism” of the left and the right. The Bulletin of the Psychonomic Society 7, 271-274. 